\title{
Aortic Stenosis: Causes and Management
}

\author{
Aisling Kinsella ${ }^{1}$, Annamalar Muthu' ${ }^{2}$, Cusimano RJ ${ }^{3}$, Eric Horlick ${ }^{4}$ and Jagdish Butany ${ }^{5 *}$ \\ ${ }^{1}$ Department of Cardiac Surgery, Toronto General Hospital-Peter Munk Cardiac Centre, Canada \\ ${ }^{2}$ Interventional Cardiology, Toronto General Hospital -Peter Munk Cardiac Centre, Canada \\ ${ }^{3}$ Cardiac Surgeon, University of Toronto, Canada \\ ${ }^{4}$ Interventional Cardiologist, University of Toronto, Canada \\ ${ }^{5}$ Pathologist, University Health Network and Canada
}

Submission: June 08, 2018; Published: August 22, 2018

*Corresponding author: Jagdish Butany, Consultant Cardiovascular Pathologist, Co-Editor-in-Chief, Cardiovascular Pathology, Professor, University of Toronto, Canada, Fax: 416-586-9901; Tel: 416-340-3003; Email: jagdish.butany@uhn.on.ca

Keywords: Aortic valve; Valvular stenosis; Prosthetic heart valves; Complications of prosthetic heart valves

\section{Introduction}

Aortic stenosis is an underappreciated yet serious and growing conundrum. As the aging population increases the incidence of aortic stenosis will increase [1]. Clinicians are encouraged to participate in a "heart team" to personalise management for each patient. As the choice of biological and trans-catheter valves increases, selection of the optimum prosthesis for a given patient becomes more complex. The balance between procedural risk, patient preference and available data on durability all contribute to this increased complexity.

\section{Aortic Stenosis}

a. Aortic stenosis causes a progressive obstruction to the outflow of blood from the Left Ventricular Outflow Tract (LVOT) to the aorta, due to the narrowing of the aortic valve orifice.
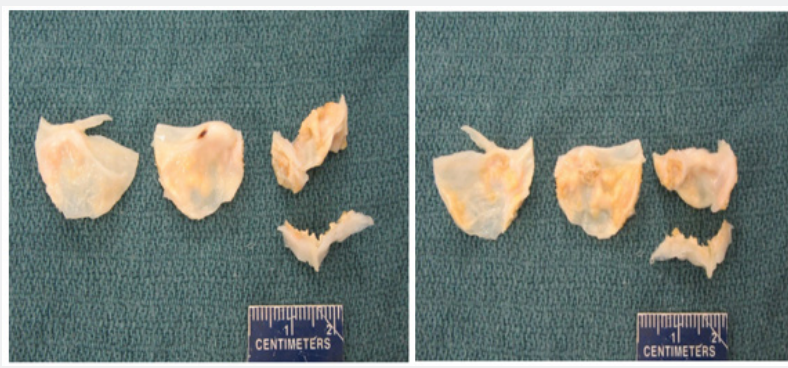

Figure 1A \& B: Figs A and B are gross images of the flow and non-flow surfaces of this surgically excised three cusp aortic valve form 77 -year-old mal All three cusps show diffuse thickening due to fibrosis and to multifocal calcification.

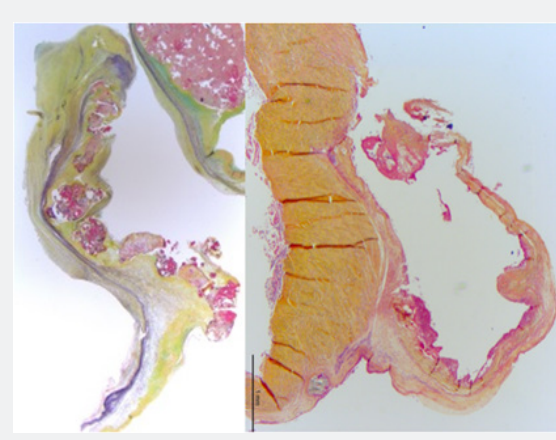

Figure 1C: This porcine aortic site bioprosthesis, shows a large tear (arrow). The adjacent cuspal tissues show thickening and finely nodular calcification. Fig B shows a histopathological image of one of the cusps with thrombus(arrow) adherent to the sinus surface of the cusp. (Stain-Movat pentachrome. Original magnification-x1.25). 


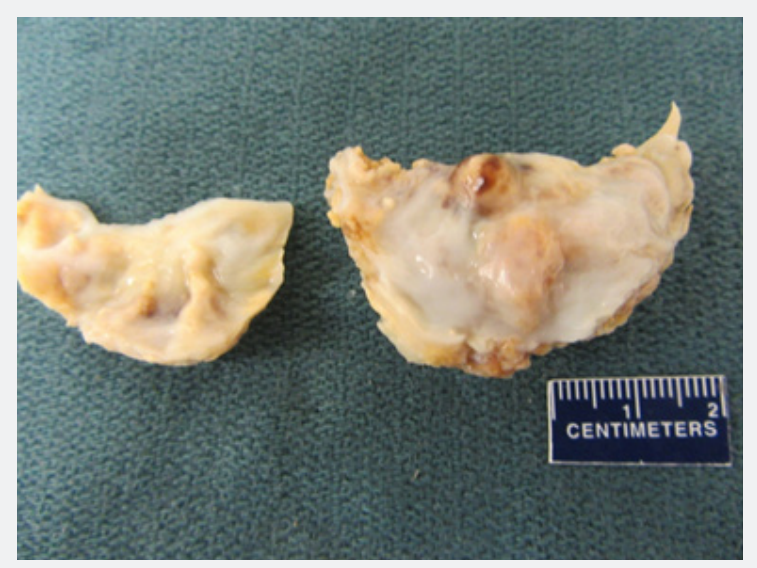

Figure 2A: shows a low power histopathological image of a longitudinal section of one cusp (a part of a second cusps section is seen in the upper right corner). The lowest part of the image shows the normal layers of a cusp, while the rest of the section shows fibrosis, thickening and multifocal calcification of the cusp, primarily in the zona fibrosa. (C. stain-Movat pentachrome. Original magnification$\mathrm{x} 1.25)$.

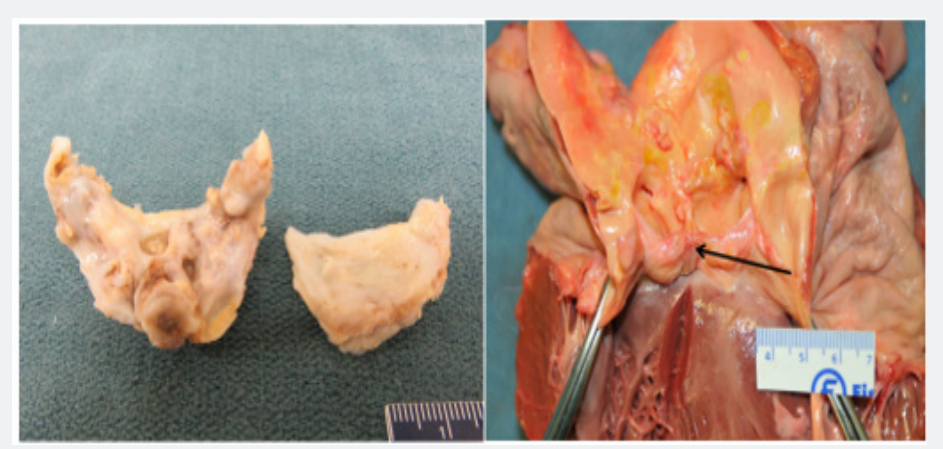

Figure 3A: Gross images of a surgically excised, congenitally bicuspid aortic valve. Both pieces of cuspal tissue show marked fibrosis, thickening and multifocal calcification. B shows the sinus surface and the raphe is seen at its middle. The latter is also markedly thickened and diffusely calcified.

b. The causes include; degenerative calcification of three cusp valves (Figure $1 \mathrm{~A}-1 \mathrm{C})$ congenital bicuspid valves $(1-2 \%$ of population) (Figure 2A \& 2B), and rheumatic fever (Figure 3 ). Each of the above results in the cusps showing increased fibrosis, thickening, stiffening and progressive multinodular calcification.

c. For people over the age of 75 years, the pooled prevalence of aortic stenosis is 3.4\% [2].

d. Patients most commonly present with angina, syncope and dyspnea, however they may be asymptomatic. The degree of obstruction can be classified as mild, moderate and severe as per the AHA/ACC guidelines [3] (Table 1).

Table 1: Grading severity of aortic stenosis.

\begin{tabular}{|c|c|c|c|}
\hline & Mild & Moderate & Severe \\
\hline $\begin{array}{c}\text { Aortic Jet } \\
\text { velocity }\end{array}$ & & & \\
\hline$(\mathrm{m} / \mathrm{s})$ & $2.6-2.9$ & $3.0-4$ & $>4$ \\
\hline Mean gradient & & $20-40$ & $>40$ \\
\hline$(\mathrm{mmHg})$ & $<20$ & $1.0-1.5$ & $<1.0$ \\
\hline AVA $\left(\mathrm{cm}^{2}\right)$ & $>1.5$ & & \\
\hline
\end{tabular}

\begin{tabular}{|c|c|c|c|}
\hline Indexed AVA & & & \\
\hline$\left(\mathrm{cm}^{2} / \mathrm{m}^{2}\right)$ & $>0.85$ & $0.6-0.85$ & $<0.6$ \\
\hline Velocity ratio & $>0.5$ & $0.25-0.50$ & $<0.25$ \\
\hline
\end{tabular}

Table 2: Indications for surgery in aortic stenosis.

\begin{tabular}{|c|c|}
\hline $\begin{array}{c}\text { Class of } \\
\text { Recommendation }\end{array}$ & Recommendations \\
\hline & Severe AS + symptoms \\
& $\begin{array}{c}\text { Severe AS + asymptomatic + EF <50\% } \\
\text { Severe AS + other cardiac surgery }\end{array}$ \\
\hline & $\begin{array}{c}\text { Very Severe AS (velocity }>5 \mathrm{~m} / \mathrm{s} \text { ) + asymptomatic } \\
\text { Severe AS + asymptomatic + reduced exercise } \\
\text { tolerance } \\
2 \mathrm{a}\end{array}$ \\
& $\begin{array}{c}\text { Severe AS + symptomatic + low-flow } / \text { low- } \\
\text { gradient }\end{array}$ \\
& $\begin{array}{c}\text { Moderate AS + other cardiac surgery } \\
\text { 2b }\end{array}$ \\
\hline
\end{tabular}




\section{Journal of Cardiology \& Cardiovascular Therapy}

Obstruction of the LVOT causes an increase in left ventricle systolic pressure, symmetrical LV hypertrophy, reduced diastolic compliance and heart failure if untreated. Valvular aortic stenosis is progressive and life threatening. Once symptoms appear, untreated patients have a poor prognosis; they will experience worsening symptoms, eventually leading to death. After the onset of symptoms, average survival is $50 \%$ at two years and $20 \%$ at five years [4]. The 2017 guidelines by the AHA/ACC summarise recommendations for intervention [3] (Table 2).

Choice of valve prosthesis depends on the patient's age, comorbidities, operative risk and individual preference (Figure $4 A \&$ B \& 5 A \& B).

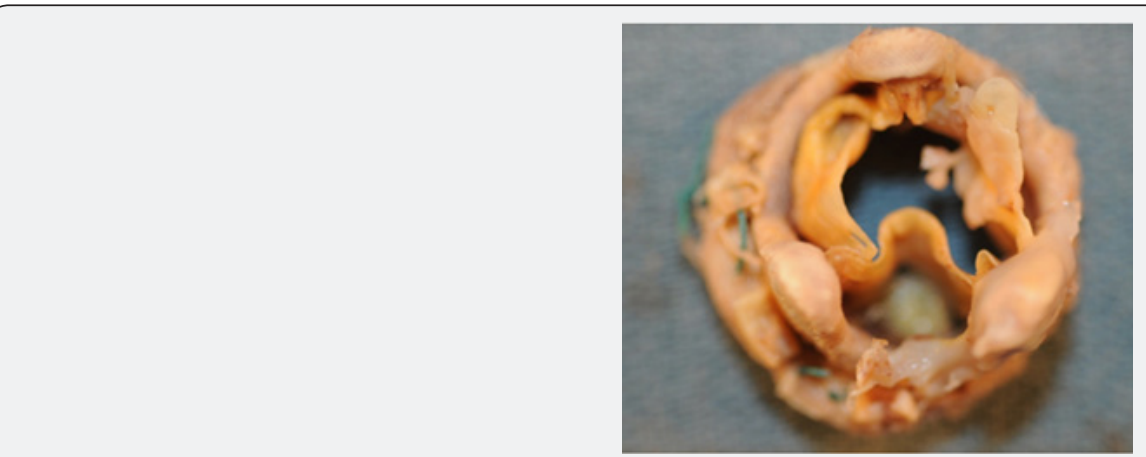

Figure 4A: The open left ventricular outflow tract, from a 57 year old man who had a history of rheumatic fever, shows the features of chronic rheumatic aortic valve stenosis. The cusps are thickened and somewhat prolapsed. The commissure (red arrow) is fibrosed, thickened and calcified.

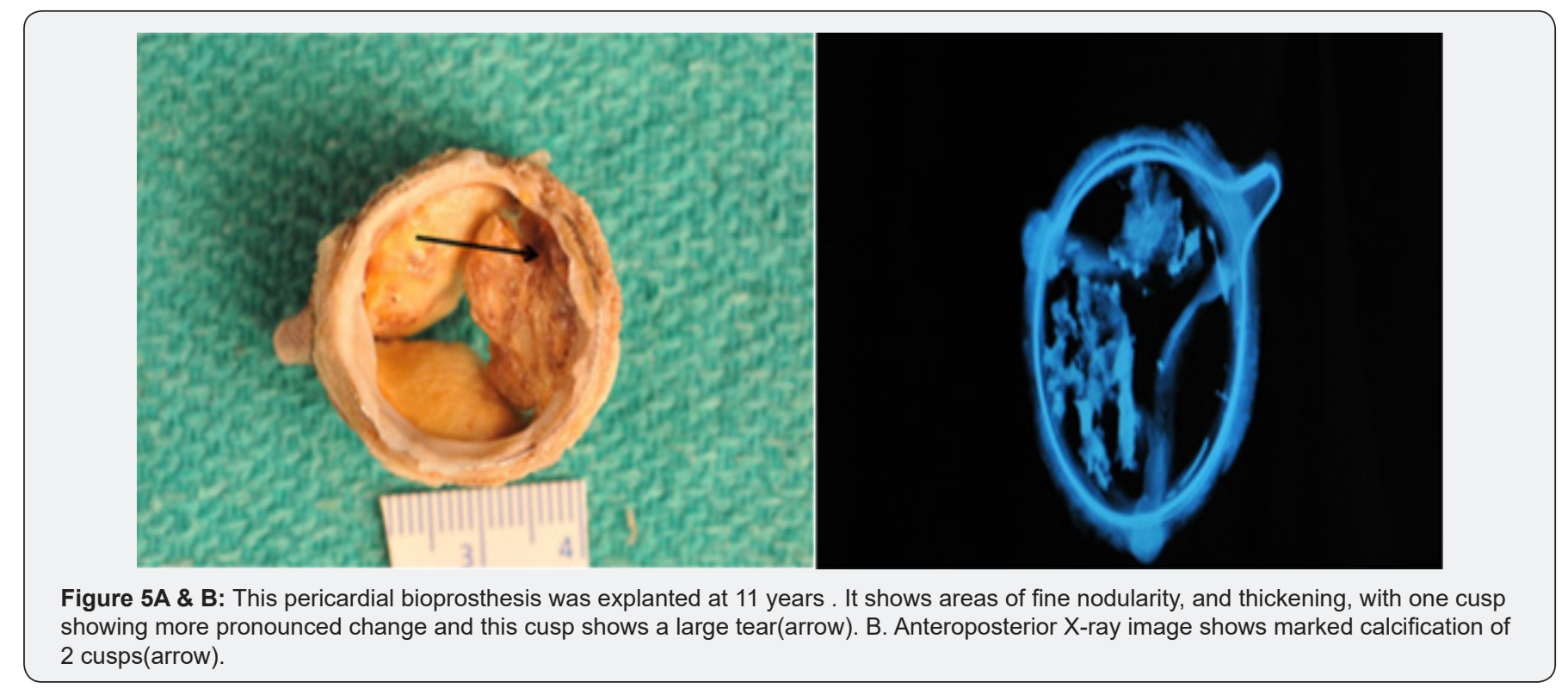

Tran Catheter Aortic Valve Implantation (TAVI) is indicated in patients with severe symptomatic AS who are not suitable for AVR as assessed by a "heart team" and should be considered in high risk patients who may still be suitable for surgery, but in whom TAVI is favoured by a "heart team" based on the individual risk profile [5]. Tran catheter Aortic Valve Implantation (TAVI) has undergone exponential technological improvements since the first successful implantation in 2002 for symptomatic severe aortic valve stenosis (AS) [6]. It is currently considered the standard of care for severe AS in patients who have high or prohibitive surgical risk, based largely on co-morbidities [5]. The indications for TAVI continue to expand now include additional patients and indications, such as those with intermediate surgical risk [7], valve-in-valve procedures [8] and bicuspid AS [9].
The transcatheter aortic valve prostheses can be divided into the Balloon-Expandable (BE) valve and self-expanding valve. A balloon-expandable aortic stent valve, consisting of a trileaflet bovine pericardial valve mounted in a stainless-steel frame, was the first BE valve prototype implanted in humans [6]. Subsequent improvements of the valve and the delivery systems resulted in a newer generations of BE prosthesis: Edwards SAPIEN ${ }^{\circ}$, SAPIEN $\mathrm{XT} \AA$ and SAPIEN $3 \AA$ valves (Edwards Life sciences, Irvine, CA) $[10,11]$. The Core Valve, Evolute R® (Medtronic Inc; Minneapolis, $\mathrm{MN}$ ), prototype of SE valves, is comprised of trileaflet porcine pericardial tissue sutured into a Nitinol ${ }^{\circledR}$ wire frame, a nickeltitanium alloy that has temperature- associated shape memory features (Figure 6A \& 6B) [11]. The TAVI valves have potential for serious complications during implantation. (Figure 7A \& 7B and Figure 8A \& 8B) \& (Figure 9). 


\section{Journal of Cardiology \& Cardiovascular Therapy}

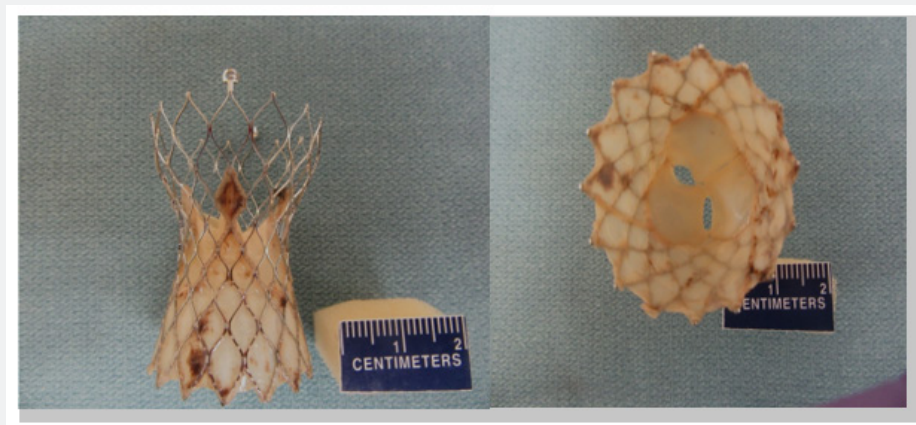

Figure 6A \& B: Images of an explanted CoreValve ${ }^{\circledR}$ showing the pericardial cusps.
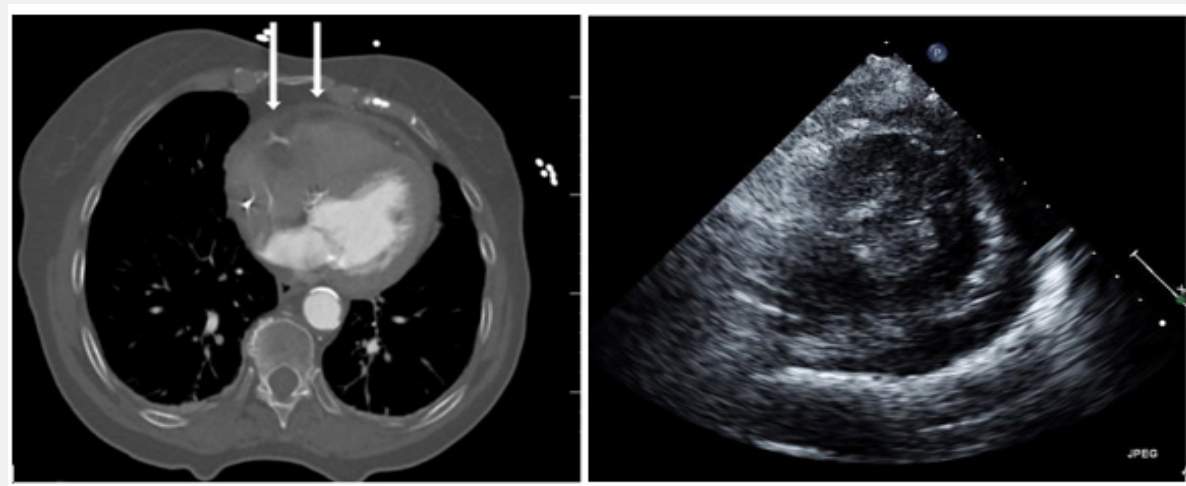

Figure 7A \& B: A/. Patient post TAVR with small hemopericardium most likely secondary to wire injury. White arrow pointing to hemopericardium. B. Large pericardial effusion post TAVR secondary to annular rupture. White arrow pointing to pericardial effusion.

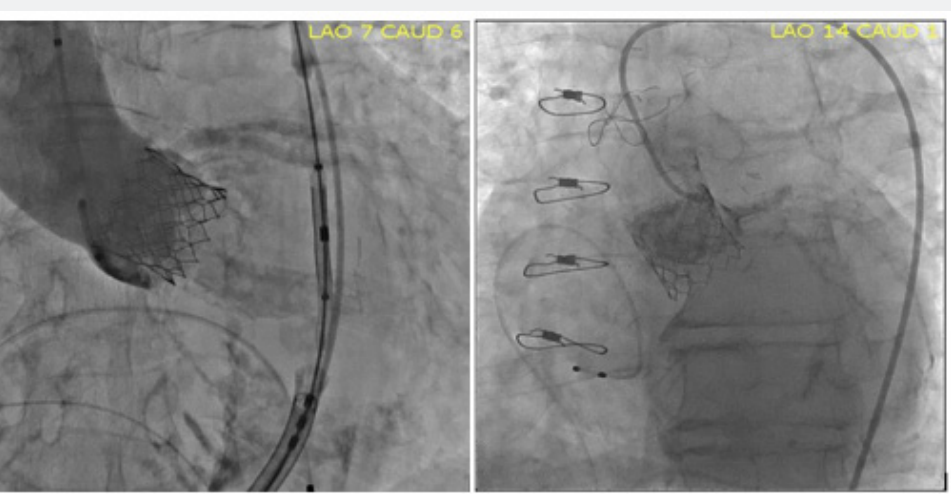

Figure 8A \& B: Annular rupture post TAVR. White arrow pointing to extravasation of contrast around the Aortic annulus. B. Left Main Coronary Obstruction post TAVR.

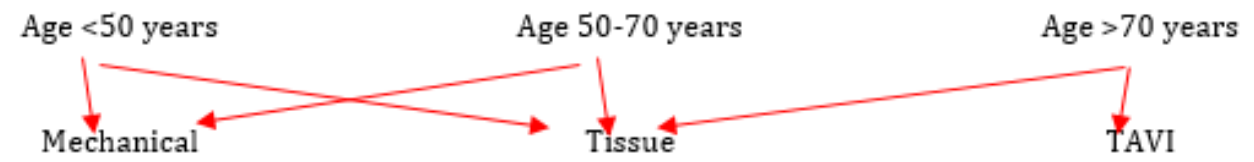

Best long-term durability

Risk of warfarin
Structural valve deterioration

Women of child bearing age

Patient preference
High surgical risk

Less data on durability

Multiple co-morbidities

Figure 9: Choice of valve prosthesis based on age. 


\section{Journal of Cardiology \& Cardiovascular Therapy}

Newer self-expanding, balloon expanding and mechanical valves such as Lotus $®$ (Boston Scientific, Natick, MA), Acurate $®$ (Symetis SA, Ecublens, Switzerland), Portico® (St. Jude Medical, St Paul, MN) (Figure 8), Centera ${ }^{\circledR}$ (Edwards Life sciences, Irvine, CA), Engager ${ }^{\circledR}$ (Medtronic Minneapolis, MN) and Jena Valve ${ }^{\circledR}$ (Jena
Valve Technology GmbH, Munich, Germany), Colibri @ (Colibri Heart Valve, Broomfield, USA), Innovare valve ${ }^{\circledR}$ (Brail Biomedical, Brazil) are the new kids on the block aiming to address potential limitations of earlier devices [12-17] (Table 3A \& 3B).

Table 3A: Complications of prosthetic heart valve devices. Early ( $<30$ days) [17].

\begin{tabular}{|c|c|c|c|}
\hline Device & M-HVD & B HVP & TAVI \\
\hline Paravalvular leak & Yes (rare) & Yes (rare) & Yes \\
\hline Infection (IE) & Yes & Yes & No (rare - minimal) \\
\hline Anticoagulant Problems & Yes & No (mild) & No (rarely - minimal) \\
\hline Persistent Gradient & Yes (mild) & Yes (rare) & Yes (rare) \\
\hline Prosthesis Dysfunction & Yes (rare) & Yes (very rare) & Yes (Rare) \\
\hline $\begin{array}{c}\text { Periaortic leak (aortic sinus / root } \\
\text { rupture) }\end{array}$ & Yes (rare) & No & Yes (rare) \\
\hline $\begin{array}{c}\text { Occlusion of Coronary ostium and } \\
\text { acute MI }\end{array}$ & No & No & \\
\hline Device "embolization"
\end{tabular}

Table 3B: Complications of prosthetic heart valve devices. Intermediate/Late.

\begin{tabular}{|c|c|c|c|}
\hline Device & M-HVD & B-HVP & TAVI \\
\hline Paravalvular leak & Yes (rare) & Yes (rare) & Yes rare \\
\hline Infection & Yes & Yes & Yes \\
\hline Prosthesis dysfunction - PTF & Yes very Rare & Yes & Yes* \\
\hline $\begin{array}{l}\text { Causes of prosthesis dysfunction } \\
\text { (\#3 above) }\end{array}$ & $\begin{array}{l}\text { Thrombosis } \\
\text { Materials failure-very rare }\end{array}$ & $\begin{array}{l}\text { Tissue degeneration } \\
\text { a) Cusp tear } \\
\text { b) Cusp calcification }\end{array}$ & Yes* \\
\hline Host Tissue Reaction & Yes - late impact & Yes - Impact significant & Yes* \\
\hline Thrombosis / Embolism & Yes & Yes-but rare & $*$ \\
\hline \multicolumn{4}{|c|}{ Clinical Effect } \\
\hline a) Stenosis & Yes & Yes (late) & * \\
\hline b) Regurgitant & Yes & Yes & * \\
\hline c) Combination & Yes & Yes & * \\
\hline Structural Failure & Very rare & Yes & * \\
\hline
\end{tabular}

\section{Conclusion}

The gold standard for treatment of severe symptomatic aortic stenosis is aortic valve replacement. The choice of optimum valve prosthesis depends on patient age, comorbidities, individual preference and calculated operative risk. All valve prosthesis is associated with their own risks and benefits. Clinicians are encouraged to work in a collaborative effort to choose the best treatment option for each patient. As more prosthetic valve options are available it is the responsibility of the clinician to rigorously evaluate new devices for durability and associated complications. It is important that groups publish their negative as well as positive outcomes to further our collective knowledge and advance patient care.

\section{References}

1. Thaden JJ, Nkomo VT, Enriquez SM (2014) The global burdeon of aortic stenosis. Prog Cardiovasc Dis 56(6): 565-571.
2. Osnabrugge RLJ, Mylotte D, Head SJ, Van Mieghem NM, Nkomo VT, et al. (2013) Aortic stenosis in the elderly: Disease prevalence and number of candidates for transcatheter aortic valve replacement: A metaanalysis and modeling study. J Am Coll Cardiol 62(11): 1002-1012.

3. Bonow RO, Carabello BA, Chatterjee K, De Leon AC, Faxon DP (2008) 2008 Focused update incorporated into the ACC/AHA 2006 guidelines for the management of patients with valvular heart disease. Circulation 118(15): e523-e661.

4. Ross J, Braunwald E (1968) Aortic stenosis. Circulation 38(1 Suppl): 61-67.

5. Baumgartner H, Falk V, Bax JJ, De Bonis M, Hamm C, et al. (2017) ESC/ EACTS Guideline for the management of valvular heart disease. Eur Heart J 38(36): 2739-2791.

6. Cribier A, Eltchaninoff H, Bash A, Borenstein N, Tron C, et al. (2003) Percutaneous transcatheter implantation of an aortic valve prosthesis for calcific aortic stenosis; first human case description. Circulation 106(24): 3006-3008. 
7. Piazza N, Kalesan B, van Mieghem N, Head S, Wenaweser $P$, et al. (2013) A 3-center comparison of 1-year mortality outcomes between transcatheter aortic valve implantation and surgical aortic valve replacement on the basis of propensity score matching among intermediate-risk surgical patients. JACC Cardiovascular Intervention 6(5): 443-451.

8. Makkar RR, Jilaihawi H, Chakravarty T, Fontana GP, Kapadia S, et al. (2014) Determinants and outcomes of acute transcatheter valve-invalve therapy or embolization: a study of multiple valve implants in the US partner trial (Placement of Aortic Transcatheter Valve Trial Edwards SAPIEN Transcatheter Heart Valve). J Am Coll Cardiol 62(5): 418-430.

9. Mytotte D, LT, SL (2014) Transcatheter aortic valve replacement in bicuspid aortic valve disease. Journal of American College of Cardiology 64: 2003-2009.

10. Ribeiro HB, Urena M, Allende R, Amat-Santos IJ, Rodés-Cabau J (2014) Balloon-expandable prostheses for transcatheter aortic valve replacement. Prog Cardiovas Dis 56(6): 583-595.

11. Kumar R, Latib A, Colombo A, Ruiz CE (2014) Self-expanding prostheses for transcatheter aortic valve replacement. Prog Cardiovasc Dis 56(6): 596-609.
12. Meredith It, Kristin LH, Haratani N, Dominic JA, Keith DD (2012) Boston Scientific Lotus valve. Euro Intervention 8: 70-74.

13. Spence MS, Lyons K, McVerry F, Smith B, Manoharan GB, et al. (2013) New St. jude medical portico transcatheter aortic valve: features and early results. Minerva Colangiologica 61(3): 263-269.

14. Sundermann SH, Grünenfelder J, Corti R, Rastan AJ, Linke A, et al. (2012) Feasibility of the engager aortic transcatheter valve system using. Eur J Cardiothorac Surg 42(4): e48-e52.

15. Binder RK, Schäfer U, Kuck KH, Wood DA, Moss R, et al. (2013) Transcatheter aortic valve replacement with a new self-expanding transcatheter heart valve and motorised delivery system. JACC Cardiovasc Interv 6(3): 301-307.

16. Kempfert J, Rastan AJ, Mohr FW, Walther T (2011) A new self-expanding transcatheter aortic valve for transapical implantation first- in-man implantation of the jenavalve ${ }^{\mathrm{TM}}$. Eur J Cardiovasc Surg 40(3): 761-763.

17. Vongpatanasin W, David H, Richards AL (1996) Prosthetic heart valves. N Engl J Med 335(6): 407-416.

\section{Your next submission with Juniper Publishers} will reach you the below assets

- Quality Editorial service

- Swift Peer Review

- Reprints availability

- E-prints Service

- Manuscript Podcast for convenient understanding

- Global attainment for your research

- Manuscript accessibility in different formats

(Pdf, E-pub, Full Text, Audio)

- Unceasing customer service

Track the below URL for one-step submission https://juniperpublishers.com/online-submission.php 